\title{
HIV/HBV coinfection: temporal trends and patient characteristics, Spain, 2002 to 2018
}

Leire Pérez-Latorre ${ }^{1}$, Juan Berenguer ${ }^{1}$, Rafael Micán², Marta Montero3 ${ }^{3}$ Carmen Cifuentes ${ }^{4}$, Teresa Puig ${ }^{5}$, José Sanz ${ }^{6}$, Oscar

L Ferrero ${ }^{7}$, Belén De La Fuente ${ }^{8}$, Carmen Rodríguez ${ }^{9}$, Sergio Reus ${ }^{10}$, José Hernández-Quero ${ }^{11}$, Gabriel Gaspar ${ }^{12}$, Laura Pérez-

Martínez ${ }^{13}$, Coral García ${ }^{14}$, Luis Force ${ }^{15}$, Sergio Velos0 ${ }^{16}$, Marta De Miguel ${ }^{17}$, Inmaculada Jarrín ${ }^{18}$, Juan González-García ${ }^{2}$, the

GeSIDA 8514 Study Group ${ }^{19}$

1. 1 Hospital General Universitario Gregorio Marañón, Madrid, Spain

2. 2 Hospital Universitario La Paz, Madrid, Spain

3. 3 Hospital Universitario La Fe, Valencia, Spain

4. 4 Hospital Son Llàtzer, Son Ferriol, Spain

5. 5 Hospital Universitari Arnau de Vilanova, Lleida, Spain

6. 6 Hospital Príncipe de Asturias, Alcalá de Henares, Spain

7. 7 Hospital de Basurto, Bilbao, Spain

8. 8 Hospital de Cabueñes, Gijón, Spain

9. 9 Centro Sanitario Sandoval, Madrid, Spain

10. Hospital General Universitario de Alicante, Alicante, Spain

11. Hospital Clínico Universitario San Cecilio, Granada, Spain

12. Hospital Universitario de Getafe, Getafe, Spain

13. Hospital General de La Rioja, Logroño, Spain

14. Hospital Universitario Virgen de las Nieves, Granada, Spain

15. Hospital de Mataró, Mataró, Spain

16. Hospital Universitari Joan XXIII, Tarragona, Spain

17. Fundación SEIMC/GESIDA, Madrid, Spain

18. Instituto de Salud Carlos III, Madrid, Spain

19. The members of the GeSIDA 8514 Study Group have been listed under Investigators

Correspondence: Juan Berenguer (jbb4@me.com)

Investigators: the Investigators are listed at the end of the article.

Citation style for this article:

Pérez-Latorre Leire, Berenguer Juan, Micán Rafael, Montero Marta, Cifuentes Carmen, Puig Teresa, Sanz José, Ferrero Oscar L, De La Fuente Belén, Rodríguez Carmen, Reus Sergio, Hernández-Quero José, Gaspar Gabriel, Pérez-Martínez Laura, García Coral, Force Luis, Veloso Sergio, De Miguel Marta, Jarrín Inmaculada, González-García Juan, the GeSIDA 8514 Study Group. HIV/HBV coinfection: temporal trends and patient characteristics, Spain, 2002 to 2018 . Euro Surveill. 2021;26(25): pii=2000236. https://doi.org/10.2807/1560-7917.ES.2021.26.25.2000236

Background: Recent and reliable estimates on the prevalence of coinfection with human immunodeficiency virus (HIV) and hepatitis B virus (HBV) in Europe are lacking. Aim: Leveraged on a study designed to assess HIV/HCV coinfection prevalence, we assessed the prevalence of HIV/HBV coinfection in Spain in 2018 and compared the results with five similar studies performed since 2002. Methods: This cross-sectional prevalence study was carried out in 43 centres, and patients were selected using simple random sampling. The reference population comprised 40,322 patients and the sample size were 1,690 patients. Results: The prevalence of HIV/HBV coinfection in Spain at the end of 2018 was $3.2 \%$. The prevalence in 2002, 2009, 2015, 2016 and 2017 was $4.9 \%, 3.4 \%, 3 \%, 3.9 \%$ and $3 \%$, respectively. Among the HIV/HBV-coinfected patients identified in $2018,16.7 \%$ had cirrhosis according to transient elastography and $26.3 \%$ tested positive for antibodies against hepatitis D virus. All HIV/HBVcoinfected patients were receiving drugs with activity against HBV, and $97 \%$ of those tested for HBV DNA had an HBV DNA load $<80 \mathrm{IU} / \mathrm{mL}$.
Conclusions: The prevalence of HIV/HBV coinfection in Spain remained stable at around 3\% for a decade. Our data could facilitate the design of national programmes to control HBV infection and help identify areas of patient management that need improvement.

\section{Introduction}

People living with human immunodeficiency virus (PLHIV) are potentially at high risk of being infected with hepatitis B virus (HBV), as both viruses share transmission routes. HIV/HBV coinfection has been associated with increased levels of HBV DNA, accelerated progression of liver disease and increased allcause and liver-related mortality [1-4].

Globally, it is estimated that $10 \%$ of PLHIV are also coinfected with HBV, although rates of coinfection vary considerably between regions and risk groups, reflecting marked differences in risk factors and HBV immunisation coverage $[1,5]$. A recent systematic review concluded that the majority of studies on HBV prevalence and incidence among PLHIV in Europe were hampered by quality issues, the most common being whether 


\section{FIGURE 1}

Prevalence of hepatitis B virus infection (HBsAg-positive) among people living with HIV, Spain, 2002-2018 $(\mathrm{n}=9,605)$

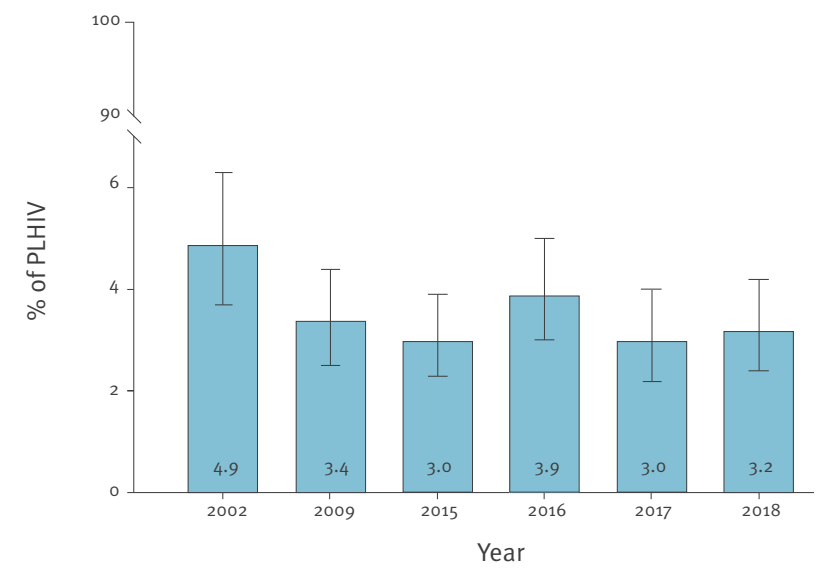

$\begin{array}{rcccccc}\text { Participating centres } & 39 & 43 & 41 & 43 & 43 & 43 \\ \text { Reference population } & 31,800 & 29,559 & 35,791 & 38,904 & 40,322 & 40,650 \\ \text { Sample size } & 1,269 & 1,458 & 1,867 & 1,588 & 1,690 & 1,733 \\ \text { Tested for HBsAg } & 92.7 \% & 97.7 \% & 97.1 \% & 97.5 \% & 96.2 \% & 96.5 \% \\ \text { Tested for HCV Ab } & 99.5 \% & 99.8 \% & 98.7 \% & 99.8 \% & 99.1 \% & 99.3 \%\end{array}$

Ab: antibodies; HBsAg: hepatitis B virus surface antigen; HCV: hepatitis C virus; PLHIV: people living with human immunodeficiency virus.

the study population was representative of the source population [6]. Studies that provide estimates of HIV/ HBV coinfection are necessary to facilitate the design of national and local programmes in order to meet the World Health Organization (WHO) goal of reducing new viral hepatitis infections by $90 \%$ and reducing deaths due to viral hepatitis by $10 \%$ by 2020 and by $65 \%$ by 2030 [7]. Estimating the burden of HIV/HBV coinfection is also relevant because some of the antiretroviral drugs to be approved in the near future, including injectable long-acting drugs, lack activity against HBV [8].

We leveraged a study on HIV/HCV coinfection prevalence to determine the prevalence of HIV/HBV coinfection in Spain in 2018, compare the results with similar studies performed in the previous 15 years and analyse patients' characteristics and treatment.

\section{Methods}

\section{Setting and design}

The study was carried out by the Grupo de Estudio del SIDA (AIDS study group; GeSIDA) of the Sociedad Española de Enfermedades Infecciosas y Microbiologıa Clınica (Spanish Society of Infectious Diseases and Clinical Microbiology, SEIMC) between 1 October and 30 November 2018, based on a similar methodology to that used in five previous studies performed in 2002, 2009, 2015, 2016 and 2017 [9]. The present national prevalence study of HIV/hepatitis C virus (HCV) and
HIV/HBV coinfections included 43 hospitals throughout Spain. The reference population comprised all PLHIV in active follow-up in the participating centres. Active follow-up was defined as at least one visit to the centre in the previous 12 months. The sample size was estimated to assess the prevalence of active HCV infection with a $95 \%$ confidence level, a design effect of 1.0 and an accuracy for the sample size of $1.25 \%$. Considering that the prevalence of active HCV infection was $8.0 \%$ in the most recent survey conducted by GeSIDA in 2017 [10], we estimated that a sample of at least 1,733 patients was needed. Given that the prevalence of HIV/ HBV coinfection was estimated to be $3 \%$ in 2017 [11], the accuracy for estimation of the prevalence of HIV/ HBV coinfection with this sample size was $0.8 \%$. The number of patients to be included at each centre was determined by proportional allocation, and patients were selected by simple random sampling.

\section{Data collection}

We collected demographic data, HIV transmission category, the United States (US) Centers for Disease Control and Prevention (CDC) category that classifies patients with HIV according to clinical and immunological parameters [13], current $\mathrm{CD}_{4}{ }^{+} \mathrm{T}$-cell counts, current HIV RNA detectability, whether patients were on combination antiretroviral therapy (ART) and the regimen used. We also recorded the presence of HBV surface antigen ( $\mathrm{HBsAg}$ ), presence of $\mathrm{HCV}$ antibodies and, if applicable, presence of HCV RNA. In patients with $\mathrm{HBsAg}$, information was also obtained about anti-HBV therapy, hepatitis D virus (HDV) antibodies, HBV DNA load and liver fibrosis. We used the cut-off values recommended by the European AIDS Clinical Society for transient elastography for the detection of advanced fibrosis and cirrhosis in patients with HIV/HBV coinfection [14]. All the information was entered into a shared database at each institution using an online electronic case report form.

\section{Data analysis}

We carried out a descriptive analysis using frequency tables for categorical variables, mean and standard deviation (SD) for normally and median and interquartile range (IQR) for non-normally distributed continuous variables. We used the chi-square test of independence to detect significant differences in categorical variables and Student's t-test and the Mann-Whitney test, respectively, to assess differences between normally and non-normally distributed continuous variables. All statistical analyses were performed using Stata, version 14.0 (StataCorp, College Station, US).

\section{Ethical statement}

The planning conduct and reporting of studies was in line with the Declaration of Helsinki, as revised in 2013 [12]. The Institutional Ethics Committee of Hospital General Universitario Gregorio Marañón approved the study (Reference: SEI-VIII-2015-01) and waived the requirement for written informed consent because the 
Baseline characteristics of the patients included in the study on the prevalence of HIV/HBV coinfection, Spain, OctoberNovember $2018(\mathrm{n}=1,733)$

\begin{tabular}{|c|c|c|c|c|c|c|c|c|c|}
\hline \multirow{3}{*}{ Characteristic } & \multicolumn{6}{|c|}{$\mathrm{HBsAg}$} & \multirow{3}{*}{$\mathrm{Pa}^{\mathrm{a}}$} & \multicolumn{2}{|c|}{ Total } \\
\hline & \multicolumn{2}{|c|}{ Unknown } & \multicolumn{2}{|c|}{ Positive } & \multicolumn{2}{|c|}{ Negative } & & \multirow{2}{*}{$n$} & \multirow{2}{*}{$\%$} \\
\hline & $\mathrm{n}$ & $\%$ & $\mathrm{n}$ & $\%$ & $n$ & $\%$ & & & \\
\hline Total & 60 & 3.5 & 54 & 3.1 & 1,619 & 93.4 & NA & 1,733 & 100 \\
\hline Male sex & 44 & 73.3 & 44 & 81.5 & 1,202 & 74.2 & 0.230 & 1,290 & 74.4 \\
\hline Mean age in years (SD) & \multicolumn{2}{|c|}{$51(10)$} & \multicolumn{2}{|c|}{$50(11)$} & \multicolumn{2}{|c|}{49 (11) } & 0.367 & \multicolumn{2}{|c|}{49 (11) } \\
\hline \multicolumn{10}{|l|}{ HIV transmission category } \\
\hline Men who have sex with men & 7 & 11.7 & 21 & 38.9 & 603 & 37.2 & \multirow{6}{*}{0.174} & 631 & 36.4 \\
\hline Injection drug use & 19 & 31.7 & 21 & 38.9 & 455 & 28.1 & & 495 & 28.6 \\
\hline Heterosexual & 15 & 25.0 & 8 & 14.8 & 440 & 27.2 & & 463 & 26.7 \\
\hline Contaminated blood products & 0 & 0 & 1 & 1.9 & 10 & 0.6 & & 11 & 0.6 \\
\hline Mother-to-child transmission & 0 & o & 1 & 1.9 & 12 & 0.7 & & 13 & 0.8 \\
\hline Other & 19 & 31.7 & 2 & 3.7 & 99 & 6.1 & & 120 & 6.9 \\
\hline \multicolumn{10}{|l|}{ CDC clinical category C [13] } \\
\hline No & 45 & 75.0 & 38 & 70.4 & 1,174 & 72.5 & \multirow{3}{*}{0.939} & 1,257 & 72.5 \\
\hline Yes & 13 & 21.7 & 15 & 27.8 & 419 & 25.9 & & 447 & 25.8 \\
\hline Unknown & 2 & 3.3 & 1 & 1.8 & 26 & 1.6 & & 29 & 1.7 \\
\hline \multicolumn{10}{|l|}{ HCV antibodies } \\
\hline Negative & 26 & 43.3 & 32 & $59 \cdot 3$ & 1,085 & 67 & \multirow{3}{*}{0.445} & 1,143 & 65.9 \\
\hline Positive & 26 & 43.3 & 22 & 40.7 & 530 & 32.7 & & 578 & 33.4 \\
\hline Unknown & 8 & 13.3 & 0 & 0 & 4 & 0.2 & & 12 & 0.7 \\
\hline HCV RNA (among the HCV antibod & & & & & & & & & \\
\hline Positive & 4 & 15.4 & 3 & 13.6 & 57 & 10.8 & & 64 & 11.1 \\
\hline Negative after anti-HCV therapy & 20 & 76.9 & 7 & 31.8 & 382 & 72.1 & $<000$ & 409 & 70.8 \\
\hline Negative spontaneous clearance & 2 & 7.7 & 12 & 54.5 & 90 & 17.0 & ro.001 & 104 & 18.0 \\
\hline Unknown & 0 & 0 & o & o & 1 & 0.2 & & 1 & 0.2 \\
\hline ART & & & & & & & & & \\
\hline Yes & 60 & 100 & 52 & 96.3 & 1,587 & 98.0 & & 1,699 & 98 \\
\hline No & 0 & 0 & 2 & 3.7 & 30 & 1.9 & 0.601 & 32 & 1.8 \\
\hline Unknown & 0 & 0 & 0 & 0 & 2 & 0.1 & & 2 & 0.1 \\
\hline Type of cART regimen (among tho & & & & & & & & & \\
\hline 2 NRTI + 1 INSTI & 23 & 38.3 & 24 & 46.1 & 701 & 44.2 & & 748 & 44.0 \\
\hline $2 \mathrm{NRTI}+1 \mathrm{NNRTI}$ & 12 & 20.0 & 17 & 32.7 & 359 & 22.6 & & 388 & 22.8 \\
\hline $2 \mathrm{NRTI}+1 \mathrm{PI}$ & 5 & 8.3 & 5 & 9.6 & 194 & 12.2 & 0272 & 204 & 12.0 \\
\hline PI-based dual therapy & 6 & 10.0 & 0 & 0 & 95 & 6.0 & 0.272 & 101 & 5.9 \\
\hline PI-based monotherapy & 2 & 3.3 & 2 & 3.8 & 54 & 3.4 & & 58 & 3.4 \\
\hline Other regimens & 12 & 20.0 & 4 & 7.7 & 184 & 11.6 & & 200 & 11.8 \\
\hline HIV RNA copies/mL & & & & & & & & & \\
\hline All patients & & & & & & & & & \\
\hline$<50$ & 52 & 86.7 & 50 & 92.6 & 1,485 & 91.7 & & 1,587 & 91.6 \\
\hline $50-200$ & 4 & 6.7 & 1 & 1.9 & 70 & 4.3 & 0.607 & 75 & 4.3 \\
\hline$>200$ & 4 & 6.7 & 3 & 5.6 & 59 & 3.6 & 0.097 & 66 & 3.8 \\
\hline Unknown & 0 & 0 & 0 & 0 & 5 & 0.3 & & 5 & 0.3 \\
\hline Patients on CART & & & & & & & & & \\
\hline$<50$ & 52 & 86.7 & 50 & 96.1 & 1,478 & 93.1 & & 1,580 & 93.0 \\
\hline $50-200$ & 4 & 6.7 & 1 & 1.9 & 69 & 4.3 & 0810 & 74 & 4.4 \\
\hline$>200$ & 4 & 6.7 & 1 & 1.9 & 35 & 2.2 & 0.819 & 40 & 2.3 \\
\hline Unknown & 0 & 0 & 0 & 0 & 5 & 0.3 & & 5 & 0.3 \\
\hline $\mathrm{CD}_{4}{ }^{+} \mathrm{T}$-cells/ $\mu \mathrm{L}$, median (IQR) & & & & & & & & & \\
\hline All patients & 598 & $0-951)$ & 637 & $-836)$ & $698(4$ & $-919)$ & 0.031 & 695( & 915) \\
\hline Patients on CART & 598 & $0-951)$ & 648 & $-842)$ & $704(4$ & $-921)$ & 0.077 & 699( & 919) \\
\hline
\end{tabular}

ART: antiretroviral treatment; CART: combination antiretroviral therapy; CDC: Centers for Disease Control and Prevention; HBsAg: hepatitis B surface antigen; HCV: hepatitis C virus; HIV: human immunodeficiency virus; INSTI: integrase strand transfer inhibitor; IQR: interquartile range; NA: not applicable; NRTI: nucleoside reverse transcriptase inhibitor; NNRTI: non-nucleoside reverse transcriptase inhibitor; PI: protease inhibitor; SD: standard deviation. Ab: antibodies; HBsAg: hepatitis B virus surface antigen; HCV: hepatitis C virus.

${ }^{a} \mathrm{p}$ values for the comparisons between $\mathrm{HBsAg}$-positive patients and $\mathrm{HBsAg}$-negative patients. 
study was based on anonymous routine clinical data intended for scientific publication.

\section{Results}

A total of 43 centres participated in the study. The reference population was 40,650 PLHIV, and the sample size was 1,733 patients, of whom 54 (3.1\%) tested positive for HBsAg, 1,619 (93.4\%) tested negative for HBsAg and 60 (3.5\%) had unknown results. Therefore, the prevalence of HBV coinfection in PLHIV in Spain in 2018 was $3.2 \%$ (95\% confidence interval $(\mathrm{Cl}): 2.4-$ 4.2). The prevalence of HIV/HBV coinfection in all the studies carried out by GeSIDA since 2002 is shown in the Figure. The prevalence of HIV/HBV coinfection in Spain was highest in 2002 (4.9\%) after which it has remained stable, varying from $3.0 \%$ to $3.9 \%$ between 2009 and 2018. Minor variations in the number of participating centres occurred along the years; however, the vast majority of hospitals remained on the same level.

The characteristics of the 1,733 PLHIV included in the 2018 survey are summarised in the Table.

In brief, $74.4 \%$ of patients were male, median age was 49 years (SD: 10) and the most frequent self-reported HIV transmission categories were men who have sex with men (MSM) (36.4\%), injection drug use (IDU) $(28.6 \%)$ and heterosexual relations (26.7\%). Prior AIDS-defining conditions (CDC clinical category C) were reported by $25.8 \%$, and $98.0 \%$ were receiving ART. The median CD4 ${ }^{+}$T-cell count was 695 (IQR: 471-915) cells/ $\mu \mathrm{L}$ and $93 \%$ of patients on ART had an HIV viral load lower than 50 copies/mL. No statistically significant differences were found between HBsAg-positive patients and HBsAg-negative patients in baseline characteristics except for a higher percentage of spontaneous clearance of HCV among the former (54.5\% vs $17.0 \%$; p 0.001 ). Information about HDV antibodies was available from 38 of 54 patients with HIV/HBV coinfection, 10 of whom had positive results. Transient elastography was performed during the previous 12 months in 30 patients with HIV/HBV coinfection: 10 patients had a value $\geq 7.6 \mathrm{kPa}$, which is suggestive of advanced liver fibrosis, and five patients had a value $\geq 9.4 \mathrm{kPa}$, which is compatible with liver cirrhosis. All $54 \mathrm{HIV} / \mathrm{HBV}$ coinfected patients were receiving antiretroviral drugs with activity against HBV, as follows: 45 received tenofovir (disoproxil fumarate or alafenamide), 36 emtricitabine, 13 lamivudine, and two received entecavir. HBV DNA had been determined in the previous 12 months in 33 patients, of whom 32 had an HBV DNA load <80 IU/ $\mathrm{mL}$ and one an HBV DNA load between 80 and 2,000 $\mathrm{IU} / \mathrm{mL}$.

Among the 1,733 PLHIV included in the 2018 survey, HCV serology was known for 1,721 patients (99.3\%), 578 of whom were HCV antibody-positive. Of the 578 patients with HCV antibodies, 409 were HCV RNAnegative following sustained viral response to antiHCV therapy, 64 patients were HCV RNA-positive, 104 had cleared HCV RNA spontaneously, and HCV RNA status was unknown for one patient. The prevalence of HCV antibodies was thus $33.6 \%$, and the prevalence of active HCV infection (HCV RNA positivity) was 3.7\%. Self-reported HIV transmission categories among 64 patients with active HCV infection were IDU $(n=50)$, MSM $(n=7)$, heterosexual relations $(n=2)$, and other/ unknown $(\mathrm{n}=5)$. Active infection by HBV and HCV was identified in three PLHIV in the 2018 survey.

\section{Discussion}

The prevalence of $\mathrm{HBV}$ coinfection among PLHIV in Spain at the end of 2018 was $3.2 \%$, almost five times higher than in the general population in Spain, which was estimated to be $0.6-0.7 \%$ in recent surveys $[15,16]$, but three times lower than the $10.4 \%$ prevalence found among PLHIV across the European Union and European Economic Area (EU/EEA) [6].

The various studies carried out by GeSIDA show that the prevalence of HIV/HBV coinfection in Spain was highest in 2002 (4.9\%) and has since remained stable, varying from $3.0 \%$ to $3.9 \%$ between 2009 and 2018 . These findings contrast considerably with the sharp decrease in the prevalence of active HCV infection in the country from $54.0 \%$ in 2002 to $3.7 \%$ in 2018 [17], indicating that HBV is likely to be the leading cause of chronic viral hepatitis among PLHIV in Spain at the time of writing. Coinfection by HBV and HCV was a highly uncommon event, recognised in less than $0.2 \%$ of PLHIV in the 2018 survey.

The persistent figures of HIV/HBV coinfection are somewhat surprising given that HBV vaccination coverage has increased steadily in Spain since its introduction in high-risk groups in 1982 [18] and given that HBV-active antiretroviral drugs with a protective effect against primary HBV infection are used frequently $[19,20]$. However, it must be taken into account that the proportion of PLHIV in Spain who were born in areas with a high prevalence of HBV infection, such as Latin America, Eastern Europe and Africa, has increased from $5.1 \%$ in 2002 to $13.7 \%$ in 2017 [21].

HDV serology was determined in approximately two thirds of HIV/HBV-coinfected patients included in this survey, $26 \%$ of whom tested positive. This percentage is 6.5 times higher than the $4 \%$ prevalence of HDV antibodies among HBV-infected patients without HIV infection in Spain [22] and 1.8 times higher than the $14.5 \%$ prevalence of HDV antibodies among HIV/HBVcoinfected patients in EuroSida [23]. Transient elastography was performed in the preceding year in slightly more than half of all patients with HIV/HBV coinfection, of whom $16.7 \%$ met the criteria for cirrhosis. This percentage is higher than the prevalence of cirrhosis in PLHIV with active HCV infection in Spain during the same year (10.9\%) [17]. All HIV/HBV-coinfected patients in this survey were receiving drugs with activity against HBV, particularly tenofovir, and HBV viral load was fully 
suppressed in almost all of those tested for HBV DNA during the preceding 12 months.

As in other reports with HIV-infected and not HIVinfected persons, we found an association between HBV infection and spontaneous clearance of HCV [2426]. Patients infected with both HBV and HCV may show a broad spectrum of virological profiles, and different viral dominance patterns have been documented [27]. In most cases, HCV is dominant and suppresses HBV replication; however, HBV can inhibit HCV replication. This is particularly true of HBV superinfection in which interferon- $\gamma$, interferon- $a$ and tumour necrosis factor-a, which are released by host inflammatory cells in response to superimposed HBV infection, have been found to inhibit replication of HCV [28].

Our study is limited by the fact that we did not assess HBV vaccination coverage and effectiveness or occult HBV infection. In addition, the small sample size of patients with HIV/HBV coinfection is a limitation to analysing other potential differences between patients with and patients without HBV as well as associations between HDV seropositivity and any other potential risk factor. However, we report robust and accurate epidemiological data on the prevalence of HIV/HBV coinfection in Spain and on patient characteristics.

\section{Conclusion}

The prevalence of HIV/HBV coinfection in Spain at the end of 2018 was $3.2 \%$, which does not differ significantly from percentages reported in studies performed over the past 15 years. All HIV/HBV-coinfected patients were on anti-HBV drugs, and HBV DNA was fully suppressed in most cases. Liver cirrhosis and HDV infection were identified as common problems among HIV/ HBV-coinfected patients. This information could facilitate the design of national programmes for control of HBV infection among PLHIV and help to identify areas of patient management that need improvement.

\section{Investigators}

The GeSIDA 8514 Study Group: C Fanciulli, P Miralles, JC López, F Parras, B Padilla, T Aldámiz-Echevarría, A Carrero, C Díez, F Tejerina, J Berenguer, V Hontañón, C Busca, A Delgado, F Arnalich, JR Arribas, JI Bernardino, R De Miguel, ML Martín-Carbonero, R Montejano, ML Montes, V Moreno, I Pérez-Valero, E Valencia, MJ Vivancos, S Moreno, A Moreno, JL Casado, MJ Pérez-Elías, C Quereda, L Domínguez, A Hernando, O Bisbal, M De Lagarde, M Matarranz, R Rubio, F Pulido, J Navarro, A Torrella, N Ramos, M Rodrigo, V Estrada, J Vergas, MJ Téllez, J Muñoz, M Gutiérrez, G Mateo, JM Guardiola, M Ibarguren, MP Carmona, F Rodríguez-Arrondo, MA Goenaga, H Azkune, MA Von Wichmann, JA Iribarren, T Brieva, A Camacho, IM Machuca, A Rivero-Juárez, A RiveroRomán, J Ruiz, E Nuño, R Palacios, J Santos, M Márquez, J Carmena, A Artero, L Morano, M Crespo, L García, S Otero, J Sanz, I Santos, J Moreno, P Arazo, C Armiñanzas, S Echevarría, M Gutiérrez-Cuadra, MC Fariñas, A Ferrer, MJ Galindo, M Tasias, S Cuellar, E Calabuig, M Blanes, I Fernández, J López-Aldeguer, M Salavert, P Domingo, J de Miguel, A Arranz, E Casas, OL Ferrero, S Ibarra, I López, M de la Peña, Z Zubero, J Baraia, J Muñoz, M Campoamor, MJ
Tuya, C Rodríguez, T Puerta, M Raposo, M Vera, J Del Romero, S Reus, L Giner, E Merino, V Boix, D Torrús, I Portilla, M Pampliega, M Díez, I Egea, J Portilla, D Vinuesa, L Muñoz, L García, JA Oteo, C García, P Barrufet, J Peraire, C Viladés, M Vargas, A Castellano, F Vidal, M Velasco, L Moreno, R Hervás, JE Losa, J Vilaró, A Cano, A Alcaráz, A Muñoz, E Bernal, A Gimeno, C Montero, S Arponen, AJ Orti, E Chamarro, C Escrig, A Chocarro, R Teira, G Alonso, C Toledo, Al Peláez, G Lara, I Fernández, MC Esteban, E Gómez-Alfaro, R Silvariño, A Vegas, P Geijo, J Bisbe

\section{Acknowledgements}

We are grateful to Thomas O’Boyle for writing assistance during the preparation of the manuscript.

Funding: This study was supported by the Spanish AIDS Research Network (RD16/0025/0017, RD16/0025/0018), which is included in the Spanish R\&D\&I Plan and is cofunded by ISCIII-Subdirección General de Evaluación and the European Regional Development Fund (ERDF).

\section{Conflict of interest}

None declared.

\section{Authors' contributions}

JB and JGG conceived and supervised the study, and interpreted the data analysis. LPL made substantial contributions to the conception and design. If analysed the data. LPL, RM, MM, CC, TP, JS, OLF, BDF, CR, SR, JHQ, GG, LPM, CG, LF, SV, MDM, MJC, and the members of the GeSIDA 8514 Study Group made substantial contributions to the acquisition of data. LPL and JB drafted the manuscript, which all authors revised critically. All authors approved the final version.

\section{References}

1. Singh KP, Crane M, Audsley J, Avihingsanon A, Sasadeusz J, Lewin SR. HIV-hepatitis B virus coinfection: epidemiology, pathogenesis, and treatment. AIDS. 2017;31(15):2035-52. https://doi.org/10.1097/QAD.0000000000001574 PMID: 28692539

2. Thornton AC, Jose S, Bhagani S, Chadwick D, Dunn D, Gilson $R$, et al. Hepatitis $B$, hepatitis $C$, and mortality among HIVpositive individuals. AIDS. 2017;31(18):2525-32. https://doi. org/10.1097/QAD.0000000000001646 PMID: 28926400

3. Kouamé GM, Boyd A, Moh R, Badje A, Gabillard D, Ouattara E, et al. Higher mortality despite early antiretroviral therapy in human immunodeficiency virus and hepatitis B virus (HBV)coinfected patients with high HBV replication. Clin Infect Dis. 2018;66(1):112-20. https://doi.org/10.1093/cid/cix747 PMID: 29020361

4. Christian B, Fabian E, Macha I, Mpangala S, Thio CL, Ulenga $\mathrm{N}$, et al. Hepatitis $\mathrm{B}$ virus coinfection is associated with high early mortality in HIV-infected Tanzanians on antiretroviral therapy. AIDS. 2019;33(3):465-73. https://doi.org/10.1097/ QAD.0000000000002073 PMID: 30702515

5. Kourtis AP, Bulterys M, Hu DJ, Jamieson DJ. HIVHBV coinfection--a global challenge. N Engl J Med. 2012;366(19):1749-52. https://doi.org/10.1056/NEJMp1201796 PMID: 22571198

6. Mason LM, Duffell E, Veldhuijzen IK, Petriti U, Bunge EM, Tavoschi L. Hepatitis B and C prevalence and incidence in key population groups with multiple risk factors in the EU/ EEA: a systematic review. Euro Surveill. 2019;24(30):1800614. https://doi.org/10.2807/1560-7917.ES.2019.24.30.1800614 PMID: 31362808

7. World Health Organization (WHO). Global Hepatitis Report, 2017. Geneva: WHO; 2017. Available from: http://apps.who. int/iris/bitstream/handle/10665/255016/9789241565455-eng. pdf? sequence $=1$ 
8. Bollinger RC, Thio CL, Sulkowski MS, McKenzie-White J, Thomas DL, Flexner C. Addressing the global burden of hepatitis B virus while developing long-acting injectables for the prevention and treatment of HIV. Lancet HIV. 2020;7(6):e443-8. https://doi.org/10.1016/S23523018(19)30342-X PMID: 31870675

9. Berenguer J, Jarrín I, Pérez-Latorre L, Hontañón V, Vivancos MJ, Navarro J, et al. human immunodeficiency virus/hepatits $C$ virus coinfection in Spain: elimination is feasible, but the burden of residual cirrhosis will be significant. Open Forum Infect Dis. 2018;5(1):ofx258. https://doi.org/10.1093/ofid/ ofx258 PMID: 29354658

10. Fanciulli C, Berenguer J, Busca C, Vivancos MJ, Domingez L, Navarro J, et al. HIV/HCV coinfection in Spain: moving fast towards elimination. Abstract \# OR-14. X Congreso Nacional GESIDA; 6-9 Nov 2018, Madrid, Spain. Available from: http://2018.congresogesida.es/images/site/ponencias/Dia3_ Jueves8/OR-09_OR-16_Auditorio/OR-14.pdf

11. Pérez-Latorre L, Berenguer J, Micán R, Montero M, Cifuentes C, Puig T, et al. HIV/HBV coinfection in Spain: temporal trends and patient characteristics (GESIDA 8514 study group). P-029 X Congreso Nacional GESIDA; 6-9 Nov 2018; Madrid, Spain. Available from: http://2018.congresogesida.es/images/site/ Revista_GESIDA_2018_web.pdf

12. World Medical Association (WMA). WMA Declaration of Helsinki - ethical principles for medical research involving human subjects. Ferney-Voltaire: WMA; 2018. Available from: https:// www.wma.net/policies-post/wma-declaration-of-helsinkiethical-principles-for-medical-research-involving-humansubjects

13. Centers for Disease Control and Prevention. From the Centers for Disease Control and Prevention. 1993 revised classification system for HIV infection and expanded surveillance case definition for AIDS among adolescents and adults. JAMA. 1993;269(6):729-30. https://doi.org/10.1001/ jama.1993.03500060023008 PMID: 8093740

14. European AIDS Clinical Society (EACS). Guidelines version 10.0 November 2019. Brussels: EACS; 2019. Available from: https:// www.eacsociety.org/files/2019_guidelines-10.0_final.pdf

15. Calleja-Panero JL, Llop-Herrera E, Ruiz-Moraga M, dela-Revilla-Negro J, Calvo-Bonacho E, Pons-Renedo F, et al. Prevalence of viral hepatitis (B and C) serological markers in healthy working population. Rev Esp Enferm Dig. 2013;105(5):249-54. https://doi.org/10.4321/S113001082013000500002 PMID: 23971655

16. Muñoz-Gámez JA, Salmerón J. Prevalence of hepatitis B and $C$ in Spain - further data are needed. Rev Esp Enferm Dig. 2013;105(5):245-8. https://doi.org/10.4321/S113001082013000500001 PMID: 23971654

17. Fanciulli C, Berenguer J, Busca C, Del Campo S, Domingez L, Navarro J, et al. HIV/HCV coinfection in Spain: Trouble will soon be over. PE37/10. 17th European Aids Conference (EACS); 6-9 Nov 2019; Basel, Switzerland.

18. Arístegui Fernández J, Díez-Domingo J, Marés Bermúdez J, Martinón Torres F. [Vaccination against hepatitis B. Impact of vaccination programmes after 20 years of use in Spain. Is it time for a change?]. Enferm Infecc Microbiol Clin. 2015;33(2):113-8. Spanish. PMID: 25620127

19. Heuft MM, Houba SM, van den Berk GE, Smissaert van de Haere T, van Dam AP, Dijksman LM, et al. Protective effect of hepatitis $B$ virus-active antiretroviral therapy against primary hepatitis B virus infection. AIDS. 2014;28(7):999-1005. https://doi.org/10.1097/QAD.0000000000000180 PMID: 24685742

20. Gatanaga H, Hayashida T, Tanuma J, Oka S. Prophylactic effect of antiretroviral therapy on hepatitis B virus infection. Clin Infect Dis. 2013;56(12):1812-9. https://doi.org/10.1093/cid/ cit145 PMID: 23487374

21. Centro Nacional de Epidemiología-Instituto de Salud Carlos III/ Plan Nacional sobre el Sida-S.G. de Promoción de la salud y Vigilancia en Salud Pública. Encuesta Hospitalaria de Pacientes con VIH/sida. Resultados 2017. Análisis de la evolución 20022017. [Hospital survey of patients with HIV/AIDS Results 2017. Analysis of the development 2002-2017. Madrid: Instituto de Salud Carlos III; 2018. Spanish. Available from: https://www. mscbs.gob.es/ciudadanos/enfLesiones/enfTransmisibles/sida/ vigilancia/InformeEncuestaHospitalaria2017_def.pdf

22. Aguilera A, Trastoy R, Rodríguez-Calviño J, Manso T, de Mendoza C, Soriano V. Prevalence and incidence of hepatitis delta in patients with chronic hepatitis B in Spain. Eur J Gastroenterol Hepatol. 2018;30(9):1060-2. https://doi. org/10.1097/MEG.0000000000001163 PMID: 29742524

23. Soriano V, Grint D, d'Arminio Monforte A, Horban A, Leen C, Poveda E, et al. Hepatitis delta in HIV-infected individuals in Europe. AIDS. 2011;25(16):1987-92. https://doi.org/10.1097/ QAD.obo13e32834babb3 PMID: 21857493
24. Thomas DL, Astemborski J, Rai RM, Anania FA, Schaeffer M, Galai N, et al. The natural history of hepatitis $C$ virus infection: host, viral, and environmental factors. JAMA. 2000;284(4):4506. https://doi.org/10.1001/jama.284.4.450 PMID: 10904508

25. Soriano V, Mocroft A, Rockstroh J, Ledergerber B, Knysz B, Chaplinskas S, et al. Spontaneous viral clearance, viral load, and genotype distribution of hepatitis C virus (HCV) in HIVinfected patients with anti-HCV antibodies in Europe. J Infect Dis. 2008;198(9):1337-44. https://doi.org/10.1086/592171 PMID: 18767985

26. Islam N, Krajden M, Gilbert M, Gustafson P, Yu A, Kuo M, et al. Role of primary T-cell immunodeficiency and hepatitis B coinfection on spontaneous clearance of hepatitis C: The BC Hepatitis Testers Cohort. J Viral Hepat. 2017;24(5):421-9. https://doi.org/10.1111/jvh.12650 PMID: 27885757

27. Mavilia MG, Wu GY. HBV-HCV coinfection: viral interactions, management, and viral reactivation. J Clin Transl Hepatol. 2018;6(3):296-305. https://doi.org/10.14218/JCTH.2018.00016 PMID: 30271742

28. Liaw YF, Yeh CT, Tsai SL. Impact of acute hepatitis B virus superinfection on chronic hepatitis C virus infection. Am J Gastroenterol. 2000;95(10):2978-80. https://doi.org/10.1111/ j.1572-0241.2000.02337.x PMID: 11051381

\section{License, supplementary material and copyright}

This is an open-access article distributed under the terms of the Creative Commons Attribution (CC BY 4.0) Licence. You may share and adapt the material, but must give appropriate credit to the source, provide a link to the licence and indicate if changes were made.

Any supplementary material referenced in the article can be found in the online version.

This article is copyright of the authors or their affiliated institutions, 2021. 